
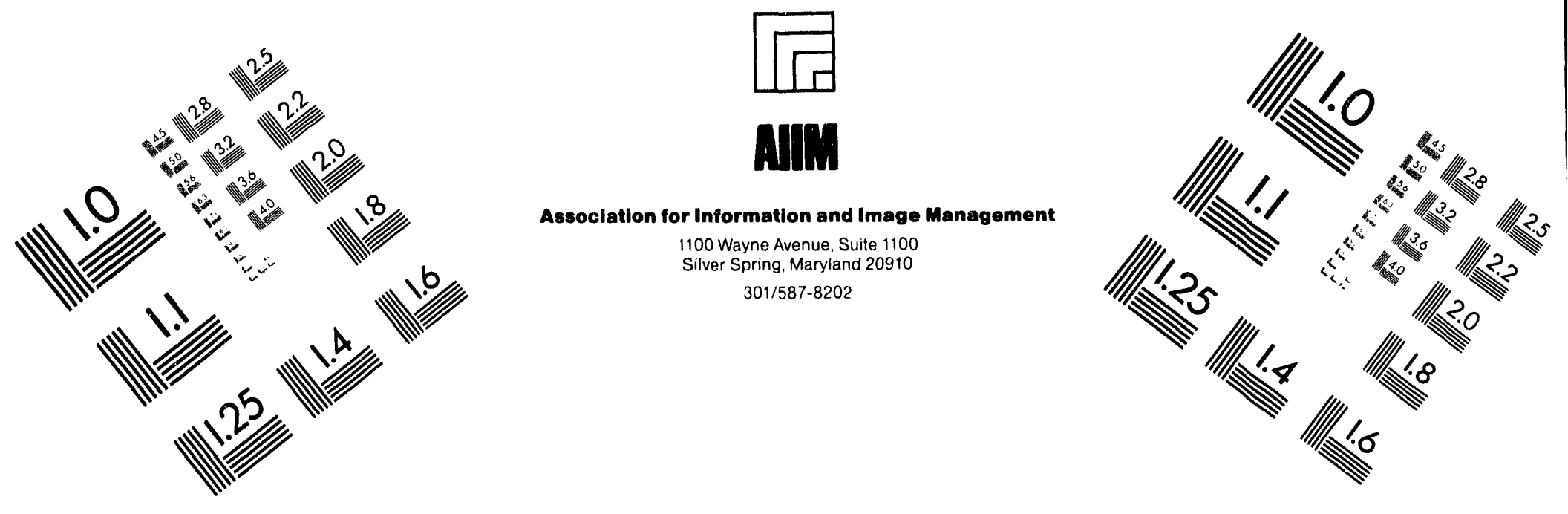

\title{
Centimeter
}

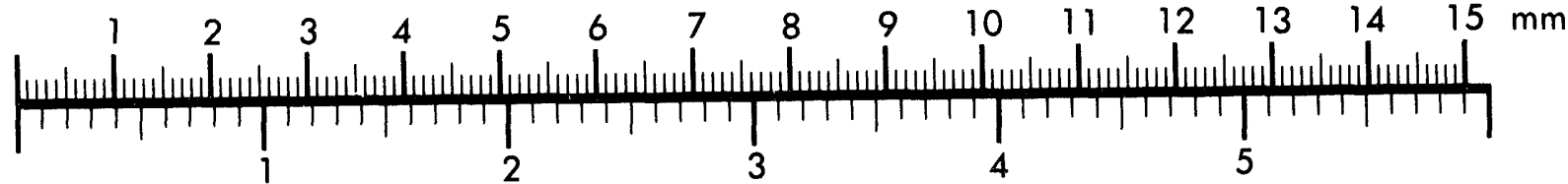

Inches
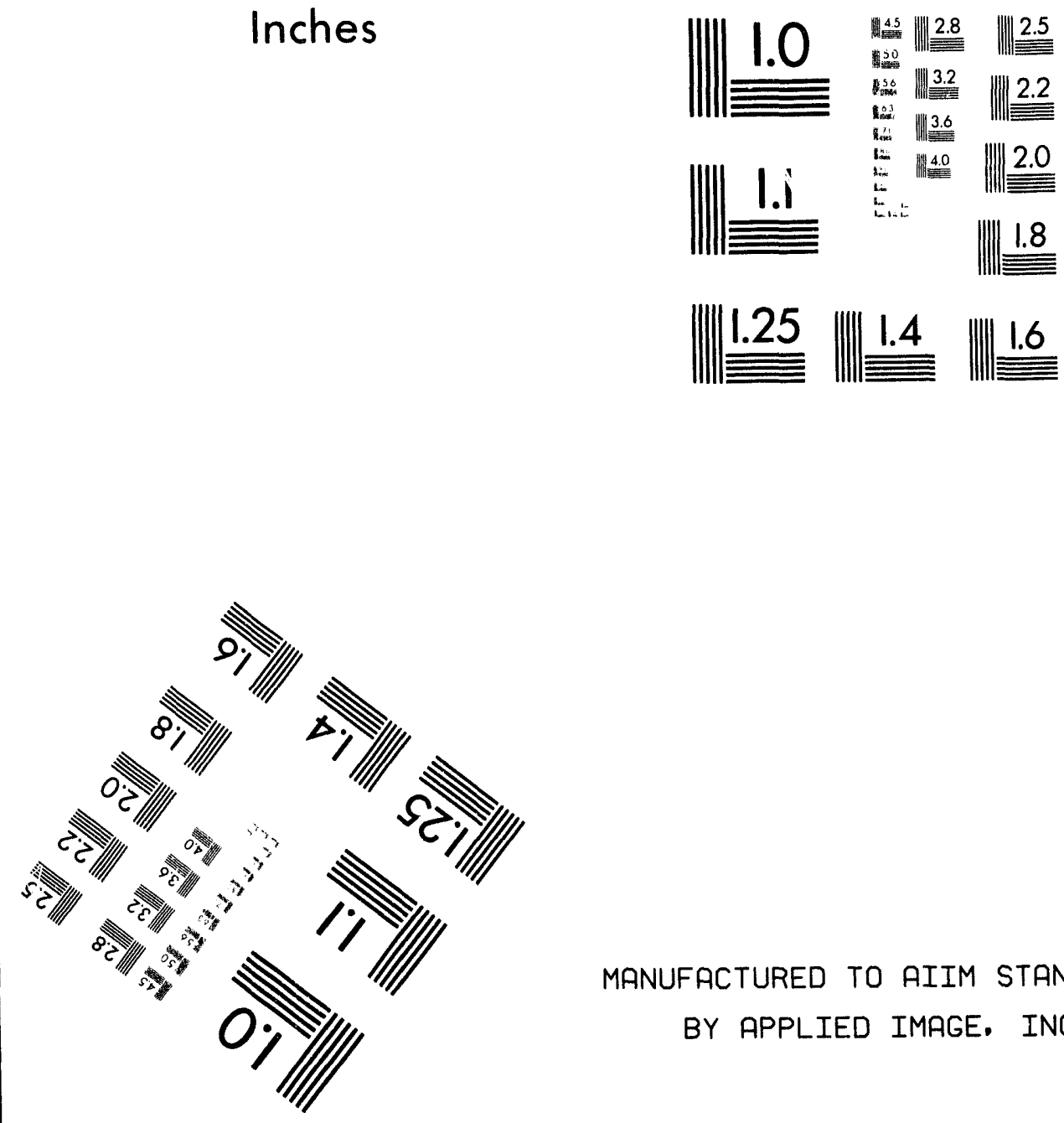

MANUFACTURED TO AIIM STANDARDS

BY APPLIED IMAGE. INC.

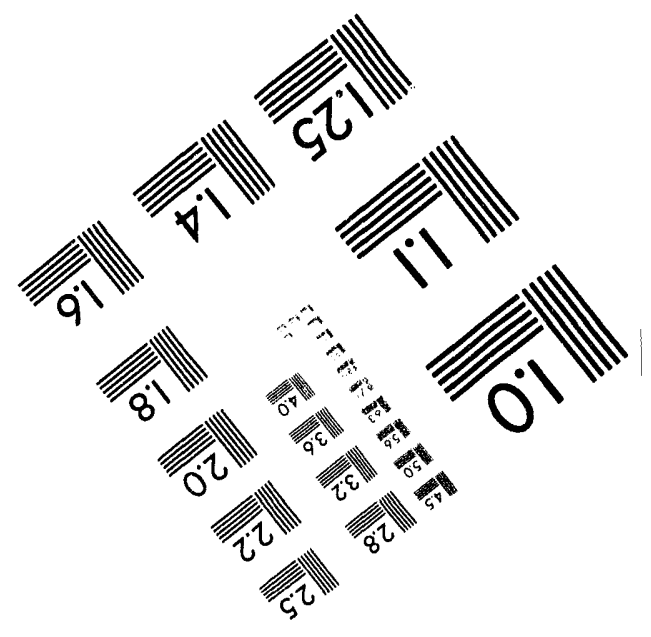



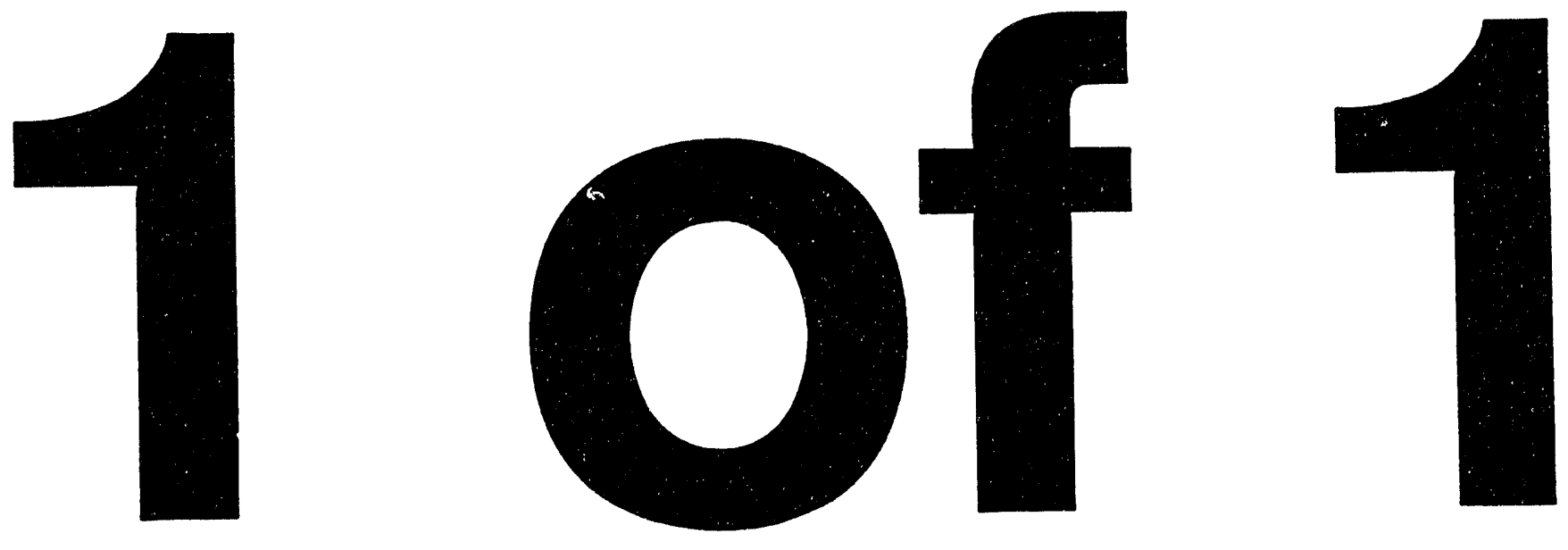


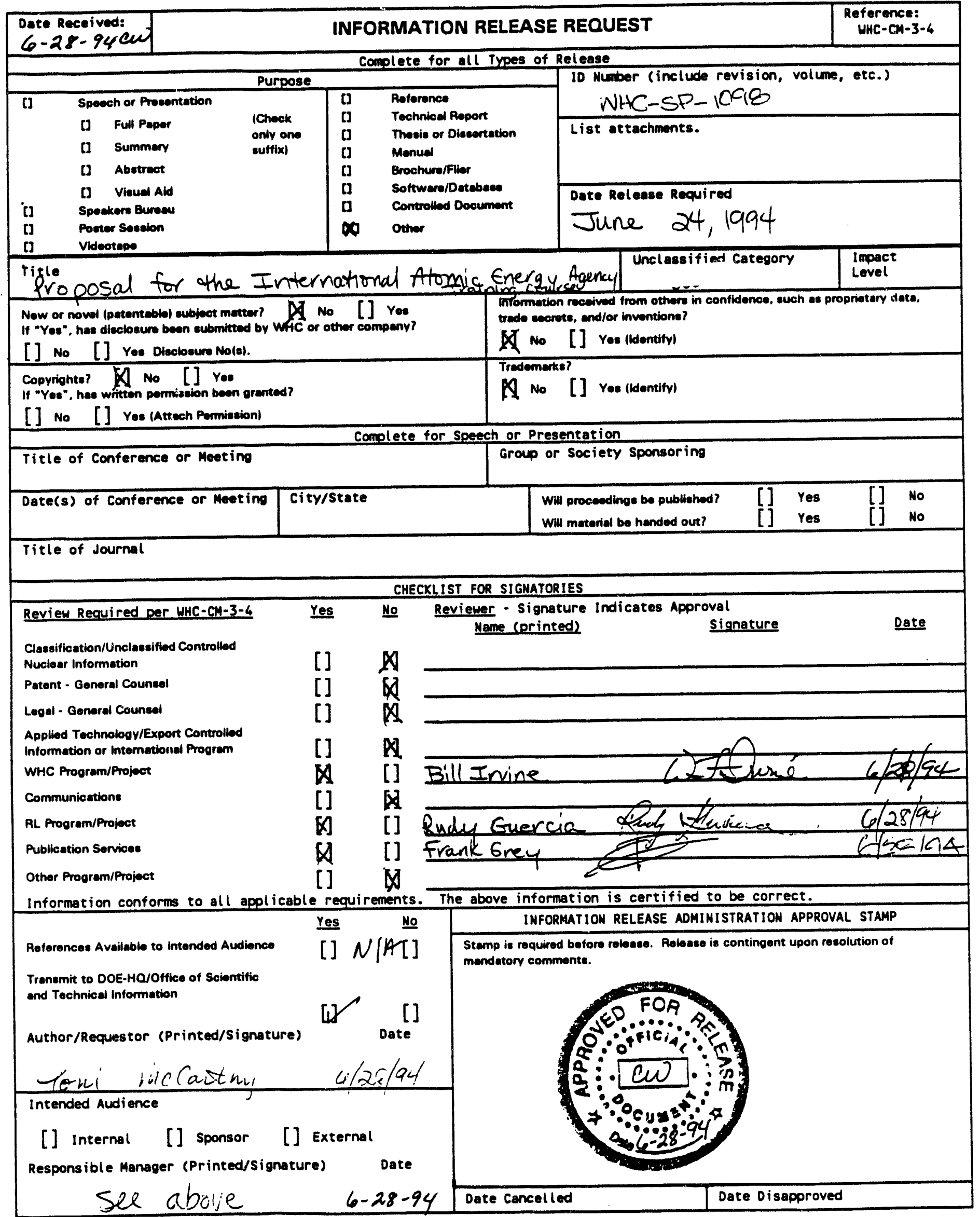




\section{Proposal for the International Atomic Energy Agency Training Course}

T. L. McCarthy

Date Published

June 1994

Prepared for the U.S. Department of Energy Office of Environmental Restoration and Waste Management

(29) Westinghouse

P.O. Box 1970

(W) Hanford Company Richland, Washington 99352

Hanford Operations and Engineering Contractor for the

U.S. Department of Energy under Contract DE-AC06-87RL10930

Approved for Public Release 
WHC-SP-1098

\author{
PROPOSAL \\ FOR \\ THE INTERNATIONAL ATOMIC ENERGY AGENCY TRAINING COURSE
}

\title{
1. LOCATION
}

Located at the confluence of the Columbia, Snake, and Yakima Rivers, the Tri-Cities (i.e., the cities of Richland, Kenriewick, and Pasco) is a beautiful sundrenched area of rolling hills and mighty rivers. The Tri-Cities is the hub of the Mid-Columbia region, just south of the Hanford Site, and has a diversified economy centered on a strong commercial, energy, and agricultural base. The typical climate during September is clear and comfortable with temperatures between $9{ }^{\circ} \mathrm{C}$ and $26^{\circ} \mathrm{C}, 48$ percent relative humidity, and only $0.9 \mathrm{~cm}$ of precipitation. See the accompanying maps of Washington State, the Tri-Cities, and the Hanford Site.

\section{MEETING FACILITIES}

All of the area's major lodging accommodations include conference facilities and smaller "breakout" rooms to accommodate any number of participants. Attendees do not require security clearances to enter these facilities. All facilities have refreshments available for participants. Standard audio/visual support equipment is available on request, and special equipment can be made available from Pacific Northwest Laboratories.

The U.S. Department of Energy's (DOE) Hazardous Materials Management and Emergency Response Training Facility (HAMMER) has several classrooms of varying size. Two classrooms can easily accommodate thirty five participants. The remaining classrooms are available for breakout cessions and training demonstrations. Adjoining the building is a large opun indoor or outdoor area available for equipment and safety prop training. Participants entering the Hammer facility will require a visitors badge.

The enclosed form is an example of what will need to be completed by the participants to receive access to any area of the Hanford Site. The Security Department per DOE order requires at least three weeks to process the paperwork. 
WHC-SP-1098

\section{ACCOMMODATIONS}

The following list is typical of lodging accommodations and their price range for the Tri-Cities:

- Red Lion Pasco
- Tower Inn Best Western
- Red Lion Hanford House
- Cavanaugh's

Dining accommodations in the Tri-Cities include these area restaurants with their corresponding fare and price ranges:

- The Boulevard

- Casa Chapala

- Henry's

- Las Margaritas

- Blue Moon

- Red Lobster

- Giacci's

- Chinese Garden

- Red Robin

- Cedar's Pier One

- Emerald of Siam

- Mandarin House
$\$ 67.00$ plus tax
$\$ 42.67$ plus tax
$\$ 69.00$ plus tax
$\$ 56.60$ plus tax.

Although, this list highlights several restaurants it does not cover all the local area dining accommodations. During the first few days of the course, a welcome reception will be scheduled at Preston Wine Cellars. An evening out will be planned for the second week at Meadow Springs Country Club and a farewell banquet will be scheduled at Bookwalter Winery.

\section{TRANSPORTATION}

Pre-arranged free transportation from the airport can be obtained from local hotel shuttle services or the Hanford Site taxi service. The Hanford Site taxi service also will be available on a pre-arranged schedule for transportatio:; around the Tri-Cities as well as for technical tours. Recreational tours will be provided by chartered bus service. 
WHC;-SP-1098

Transportation around the Tri-Cities also is provided by the local bus transit system for $\$ .40$ for adults. A map of the local bus transit service is included.

\section{TECHNICAL DEMONSTRATIONS AND TOURS}

Listed below are seven half-day technical tours and a general site tour that cover transportation, safety, and operations. Each tour will be conducted during the three week course depending on when the pertinent training topic is presented. As various technologies are continually being developed onsite, additional tours may be available in two years.

TOUR A: The Hanford Site road tour, which includes a visit to retired reactors and the old townsites of Hanford and White Bluffs and a drive through the 200 Areas where Viaste Management and Environmental Cleanup activities are being completed. This provides a general feel for the size of the Site, a historical perspective, and progress made. This will be given the first day to familiarize the class with the Hanford Site.

TOUR B: The Central Waste Complex, T Plant (Decontamination Equipment), Burial Grounds, waste shipment viewing, Transuranic Waste Storage and Assay Facility (TRUSAF), and the Waste Receiving and Processing Facility (WRAP) construction site.

TOUR C: The Fuels Material Examination Facility including the Automated Storage Vault and Automated Mixed Oxide fuel production line and Hot Cell, Siemens (Commercial Fuel Production), and the Washington Public Power Supply System (Commercial Reactor).

TOUR D: The B Plant/Waste Encapsulation Storage Facility (WESF), and Cesium Capsule shipment viewing (based on schedule availability).

TOUR E: The HAMMER demonstration and tour of the facility construction site.

TOUR F: Battelle's Pacific Northwest Laboratories (PNL) to view testing, packaging, high-level waste vitrification labs/demonstrations, robotics, in-situ vitrification (ISV) technologies (including bioremediation and low-level waste vitrification), the ISV Site, and Hanford Site technology tours that become available in two years. 
WHC-SP-1098

TOUR G: The U.S. Ecology site tour/demonstration (Washington State's low-level waste site).

TOUR H: Emergency Preparedness facilities for the DOE: Emergency Control Center (ECC) in the Federal Building, Emergency Operations Center, Joint Information Center, and the Washington Public Power Supply System ECC.

TOUR I: A tour of Tank Farms, including 101 SY high level waste Tank Farms and the Data Acquisition and Control System (DACS) trailer.

Several other areas of interest included on the Hanford Site. The Washington Public Power Supply System is a joint operating agency and municipal corporation. It leases land on the Hanford Site from the DOE for WNP-2, Washington State's only commercial nuclear power plant.

The U.S. Ecology is licensed by the Nuclear Regulatory Commission and Washington State to operate a commercial low-level radioactive waste site. The Hanford Site land is leased by Washington State from DOE. The waste is received from hospitals, research facilities, industry, and nuclear power stations.

\section{RECREATIONAL OPPORTUNITIES}

Numerous weekend recreational opportunities are available in the area and participants will be able to select from varied activities including: a visit to the Indian Cultural Center located in Yakima, Washington; the Pendleton Roundup (rodeo) in Pendleton, Oregon; a tour and laserlight show at the Grand Coulee Hydroelectric Dam; a tour of Seattle, Washington, including attending a professional sporting event (Football, Baseball, or Soccer); rafting on the Yakima River; a local winery tour; and a trip to Mt. St. Helens or Mt. Rainier. Transportation will be provided by either the Hanford Site taxi service or chartered bus, and meals will be catered or arranged at local restaurants at the destinations.

Major events occurring during September and local points of interest for the region include an International Air Show, the Great Prosser Balloon Rally, Franklin County Historical Museum, Hanford Science Center, Tri-City Chinook Professional Basketball or Tri-City Americans Professional Hockey, Mid-Columbia Symphony, East Benton County Historical Museum, Maryhill Museum, and a Jazz Festival. The Tri-Cities have eight local golf courses available to enjoy a round of golf. 
WHC-SP-1098

\section{EXPERIENCE WITH SIMILAR ACTIVITIES}

The Hanford Site has hosted similar activities, including both Hanford Summits I and II. The Hanford Summits were two-day televised events to discuss the commitment of the current Presidential administration to the environmental restoration of the Hanford Site. Public involvement and strategic issues established from Hanford Summit I include: regulatory issues, training and education, economic development and partnership, and technology transfer. Hanford Summit II provided a summary of how Secretary of Energy O'Leary is proceeding on the above strategic issues.

The DOE and Westinghouse School for Environmental Excellence frequently offers a six-week course for environmental professionals and workers. Approximately thirty to forty individuals attend the training course, which provides training in environmental regulation compliance.

The Hanford Site has hosted two previous International Atomic Energy Agency training courses. The courses lasted two weeks and had approximately eight to ten participants. Nuclear Material Management and Neutron Monitoring were the courses hosted by the Hanford Site.

PNL, Westinghouse Hanford Company, and the DOE recently sponsored a one-week workshop for fifteen Russian delegates on environmental restoration, waste management, and innovative technologies. The course included regulation issues and public awareness.

PNL also hosted Japan Nuclear Fuel Industries in a training course on the construction and operation of waste management facilities. The course lasted two to three months for participants.

PNL and the U.S. Department of Commerce participate in the Special American Business Internship Training. This course lasts three to four months for approximately twenty-five to thirty people who train for environmental assessment of nuclear accidents. conventions.

In addition, the Hanford Site also has hosted several International Delegate 


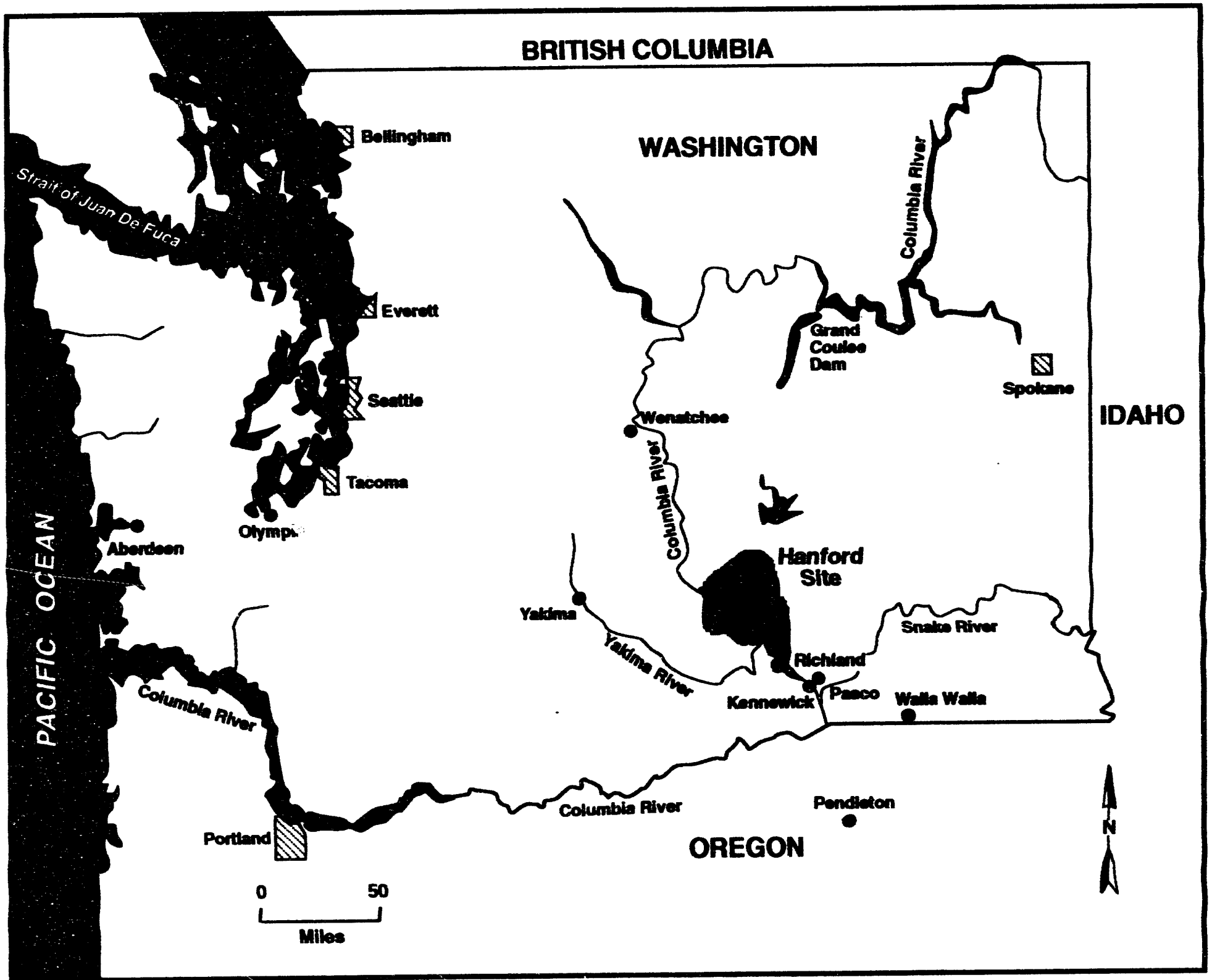

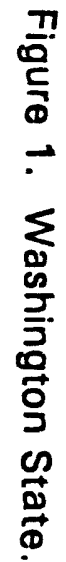




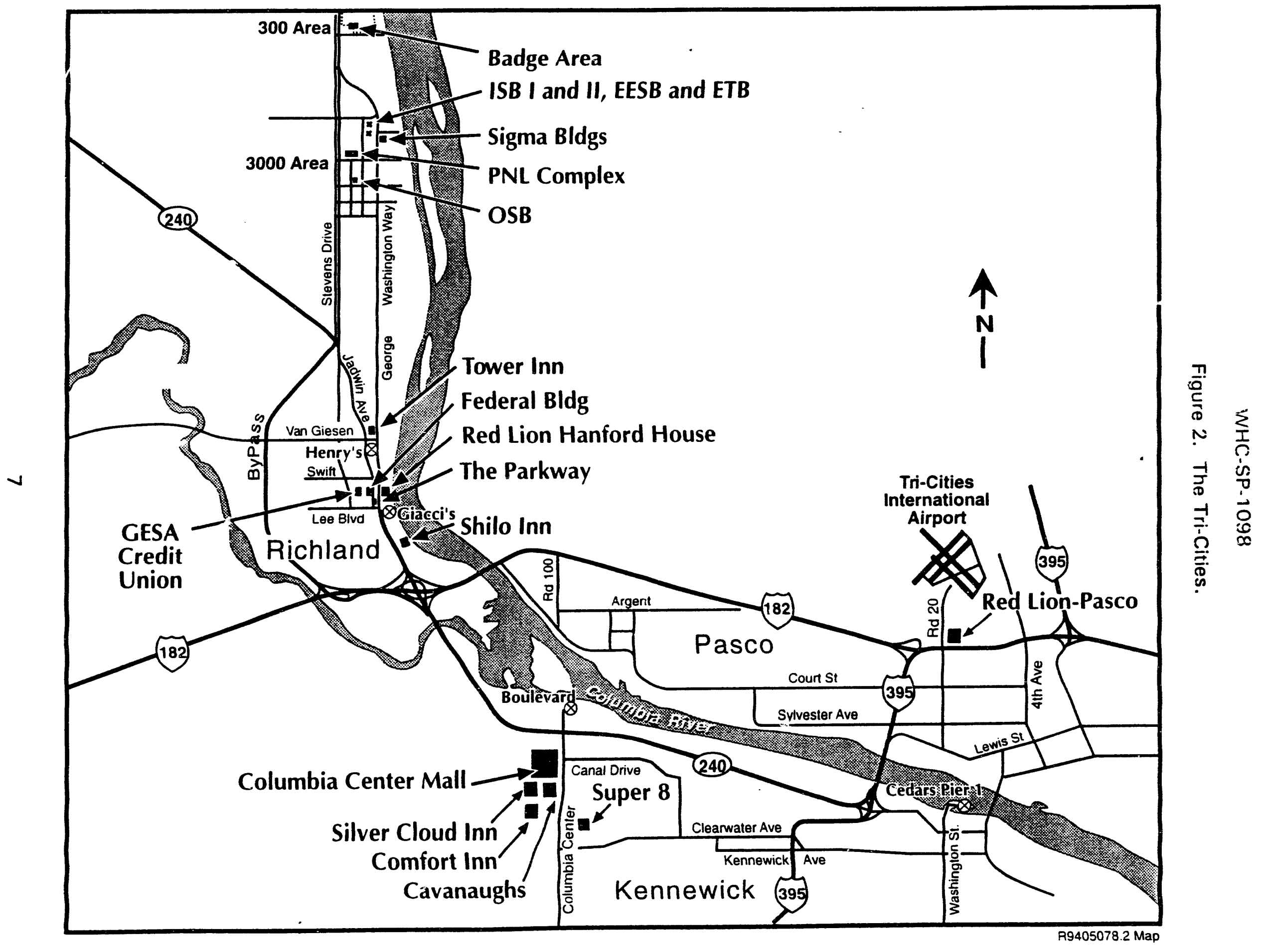


WHC-SP-1098

Figure 3. The Hanford Site.

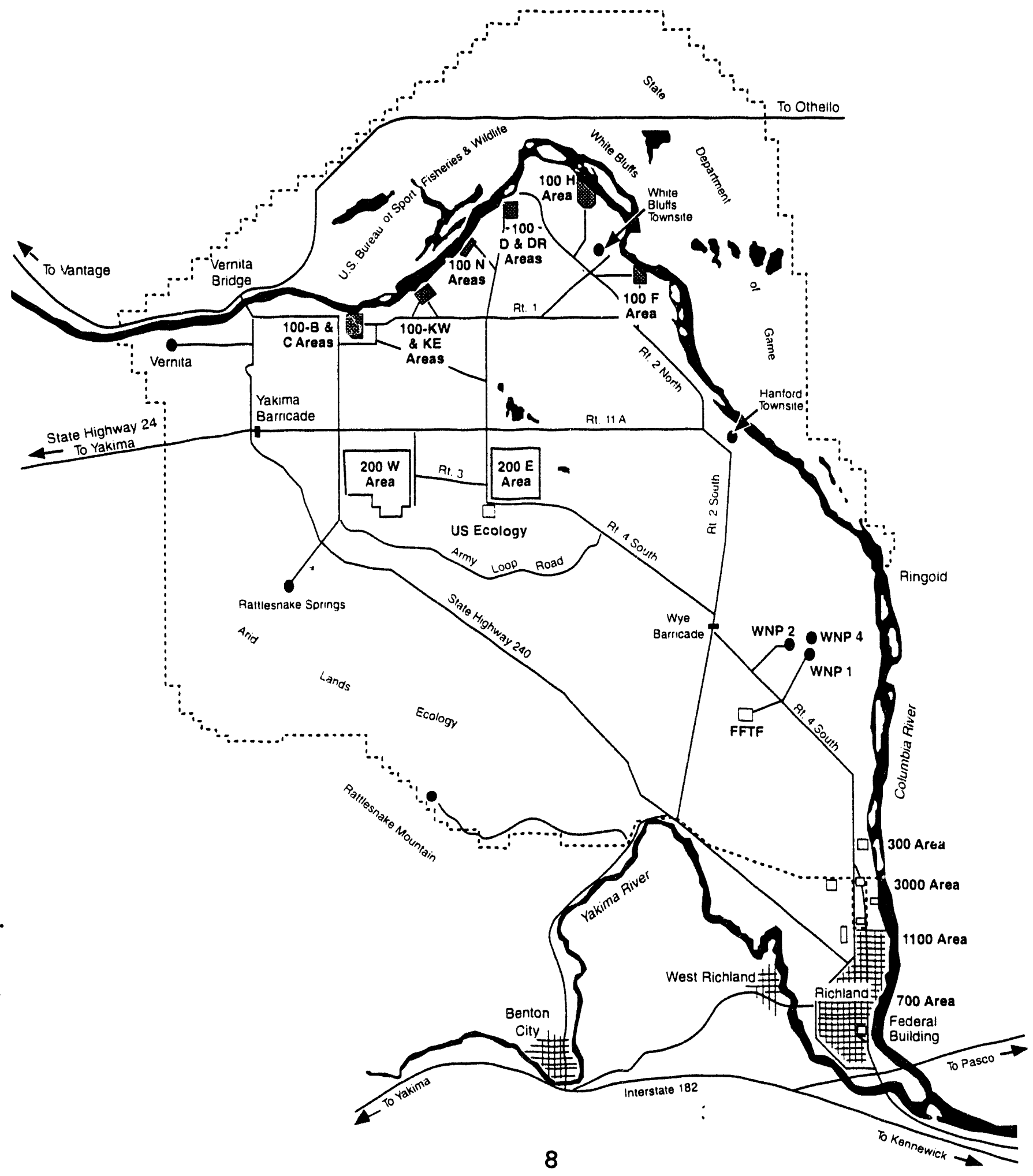


WHC-SP-1098

Figure 4. Transit Routes.

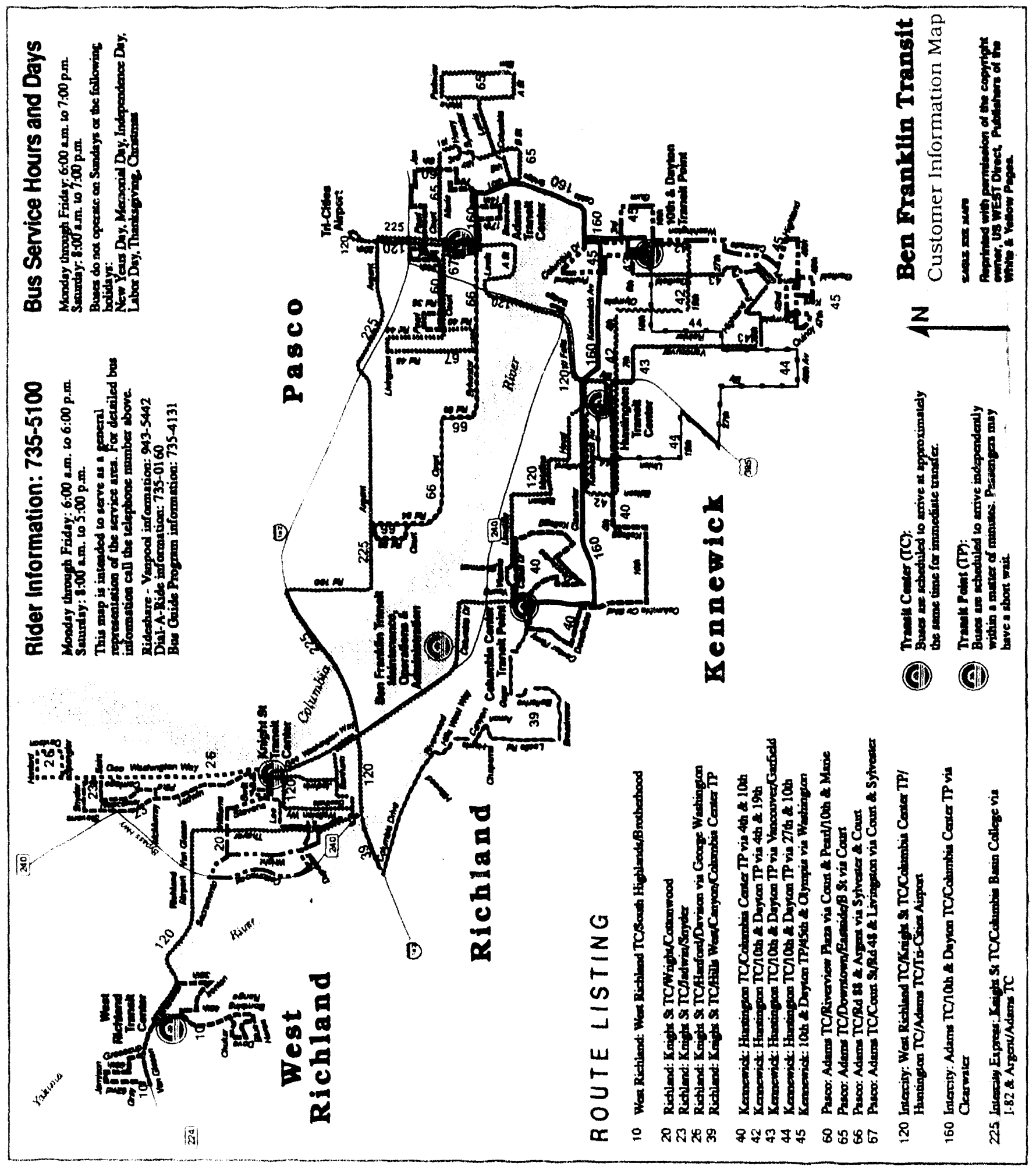




\section{Office of International Affairs \\ Rev. 1A-473 REQUEST FOR FOREIGN NATIONAL UNCLASSIFIED VISIT OR ASSIGNMENT}

PRIVACY ACT STATEMENT - Collection of the information is authorized pursuant to the Atomic Energy Act of 1954, as amended, 42 U.S.C. 2011 and the Department of Energy Organization Act, Pub. L. No. 95-91. The primary purpose of the requested information is to determine unclassified access to facilities operated by the Department of Eneroy (DOE) or its contractors. Access to the information collected may be provided to appropriate Federal agencies for law enforcement purposes. Collection of the information is mandatory. Failure to provide the information may result in denial of access to DOE or contractor facilities.

BURDEN DISCLOSURE STATEMENT - Public reporting burden for this collection of information is estimated to average 3.5 hours per response, including the time for reviewing the instructions, searching existing data sources, gathering and maintaining the data needed, and completing and reviewing the collection of information. Send comments regarding this burden estimate or any other aspe t of this collection of information, including suggestions for reducing this burden, to U.S. Department of Eneray, Office of Information and Resources Policy, Plans and Oversight, Paperwork Reduction Prcjict (1910-2100), 1000 Independence Avenue, S. W., Room F-318/GTN, AD-241.2, Washington, D. C. 20585, and to the Office oi Management and Budget (OMB), Paperwork Reduction Project (1910-2100), Washington, D. C. 20503.

\section{PART I PERSONAL DATA}

1. Nane of Visitor (Family, Given, Middle)

2. Visitor Number

3. Request Number *

\begin{tabular}{|c|c|c|c|c|c|}
\hline $\begin{array}{l}\text { 4. Gender of Visitor } \\
\text { of Birth (DD-MA-YY) } \\
\text { Male [] Femle [] }\end{array}$ & 5. Place of Birth (City Cou & ntry) & $\star$ & $\bullet$ & 6. Date \\
\hline $\begin{array}{l}\text { 7. Cointry of Citizenship } \\
\text { Expiration Date (DO-MM-YY) }\end{array}$ & $\star \quad$ & Passport Number & & & 9. \\
\hline
\end{tabular}

10. Immigrent Alien Y/W []

11. Interpreter Needed? 12. Work Telephone and/or Telex No. or Fax. No. (enter type and number)

13. Nane and Address of Current Employer 14. Name and Address of Place of Hork (if different from 13)

Name:

Name:

\begin{tabular}{|c|c|c|c|}
\hline \multirow{2}{*}{$\frac{\text { street: }}{\text { City: }}$} & \multirow[b]{2}{*}{ State/Province: } & \multicolumn{2}{|c|}{ Street: } \\
\hline & & Cfty: & State/Province: \\
\hline 2ip Code: & Division: & Zip Code: & \\
\hline Country: & & Country: & - \\
\hline
\end{tabular}

15. Title, Position or Description of Visitor's or Assignee's Duties 


\section{WHC-SP-1098}

PART II VISIT/ASSIGMMEMT DATA

PART IIA VISIT/ASSIGMMENT REQUEST INFORMATION

16. Dote of Request (Do-MH-YY) 17. This request is for (Check appropriate box)

18. visitor currently in U.S.

Visit [ ], Assignment [ ], Assignnent Extension [ ] ] Y/N [ ]

19. (For assignment only) Will you require an 20. (for assigrment only) is the assignment for intermittent periods? Exchenge Visitor (J-1) Vise? Y/N [ ] Y/N [ ]

21. Identify specific International Agreenent, if any.

22. Nem of DOE Contset

23. DoE Contact Organization

24. DOE Contact Telephone Number

25. Mame of Financial Spinsocost (Sponsor other than DOE)

PART IIB VISIT/ASSIGMMEMT FACILITY INFORMATION

27. Facility or Organization to be Visited/Assigned Code Security Sensitiveabivanidied Dates (DD-MON-YY)
Start Neme: End

Location:

29. Name of Host responsible for the Visit/Assigment

30. Host's Telephone Number

$* \quad *$

31. Building and Room Numbers

32. Nuber of daye on site

-

33. Programmatic Visit/Assignment Y/N []

34. Subject Codes

35. Subjects to be discussed or statement of research in which you wish to be assigned. (Sensitive subject $Y / N$ [I) 


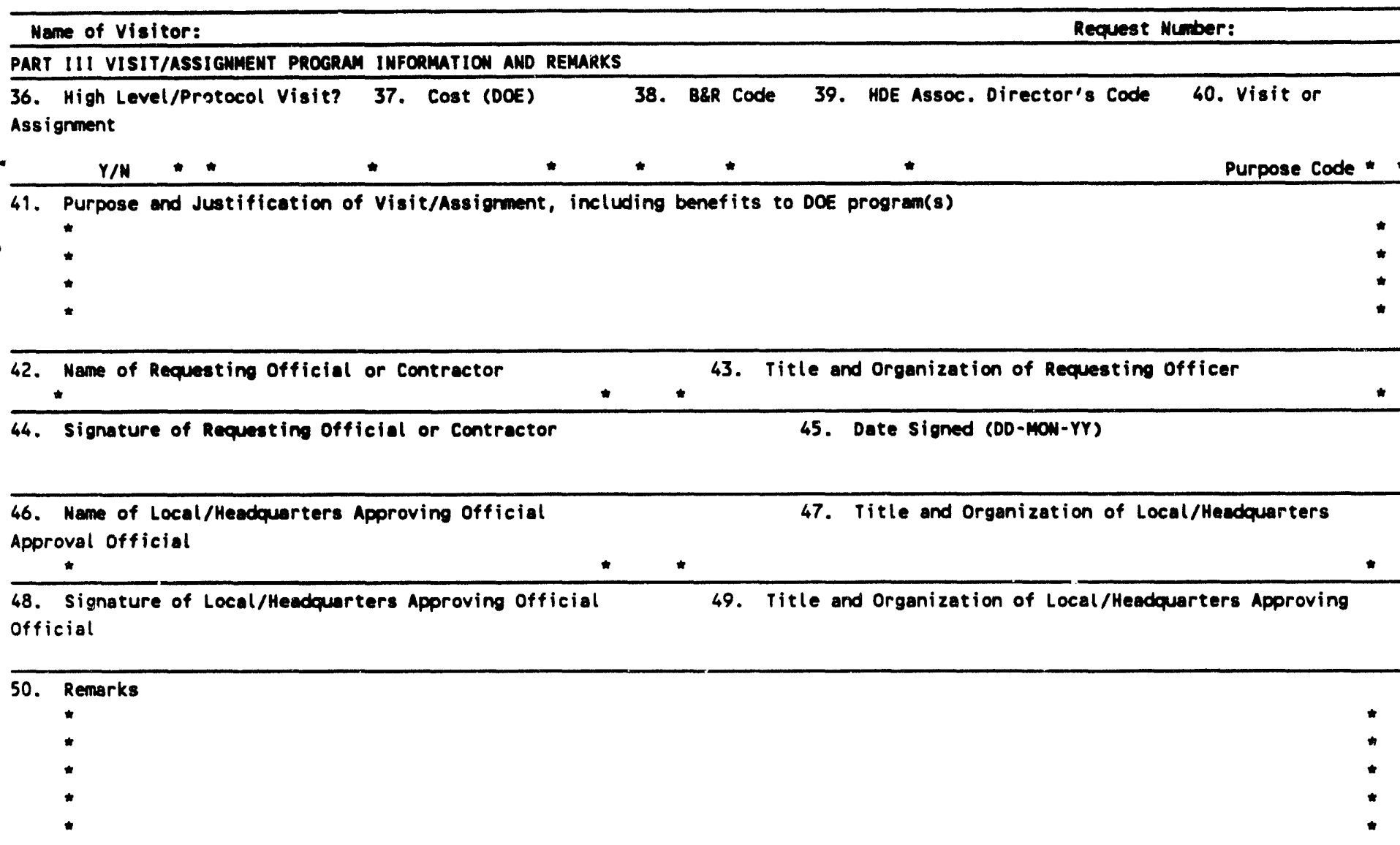

PART IV MISCELLANEOUS INFORMATION (MANDATORY FOR DOE SPONSORED V/AS, AND IAP-66 APPLICATIONS)

51. Type of Visa 52. Expiration Date of Visa (DD-Mon-YY)

53. Kind of Business or Organization of Assignee's Employer (e.g. government, company, laboratory, university)

54. Educational background (include university/college training with degrees and dates conferred)

\section{Field of Reseerch}

56. Family menbers tho will accompany or join the applicant later.

- Name (Fanily, Given, Middle):
Date of Birth (DD-MON-YY)
City, Country of Birth

- $\frac{\text { Citizenship }}{\text { Name (Family, Given, Middle): }}$

Date of Birth (DD-MOW-YY)

- Relationship

Citizenship

City, Country of Birth

Name (Family, Given, Middle):

Date of Birth (DO-MON-YY)

Citizenship

\section{- Relacionship}

Name (Family, Given, Middle):

Date of Birth (DO-MON-YY)

City, Country of Birth

- Relationship

Citizenship

City, Country of Birth

- Relationship 
WHC-SP-1098

DISTRIBUTION

Number of copies

OFFSITE

1

U.S. Department of Energy-

Headquarters

M. Wangler

\section{ONSITE}

3

U.S. Department of Energy-

Richland Operations Office

S. K. Moy

(3)

S7-55

9

Westinghouse Hanford Comoany

W. F. Irvine

G2-02

D. L. McCall

G2-02

T. L. McCarthy

G2-02

Central Files

L8-15

Document Procssing and

Distribution

(2)

L8-04

Information Release

Administration

(3)

L8-07 

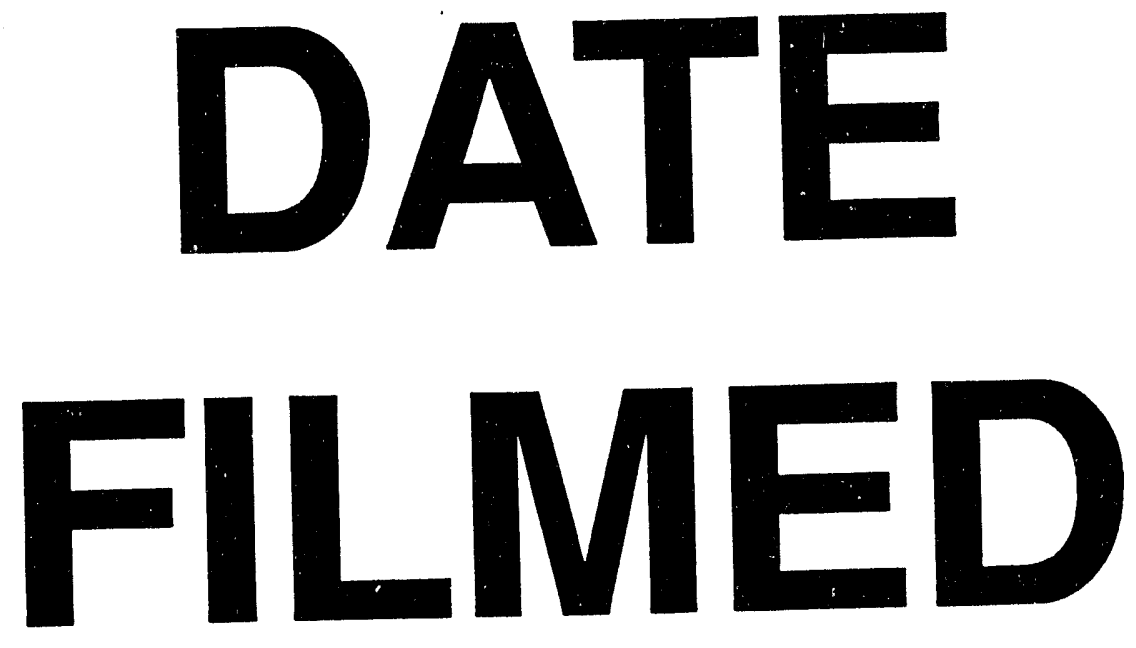

$9 / 29 / 94$
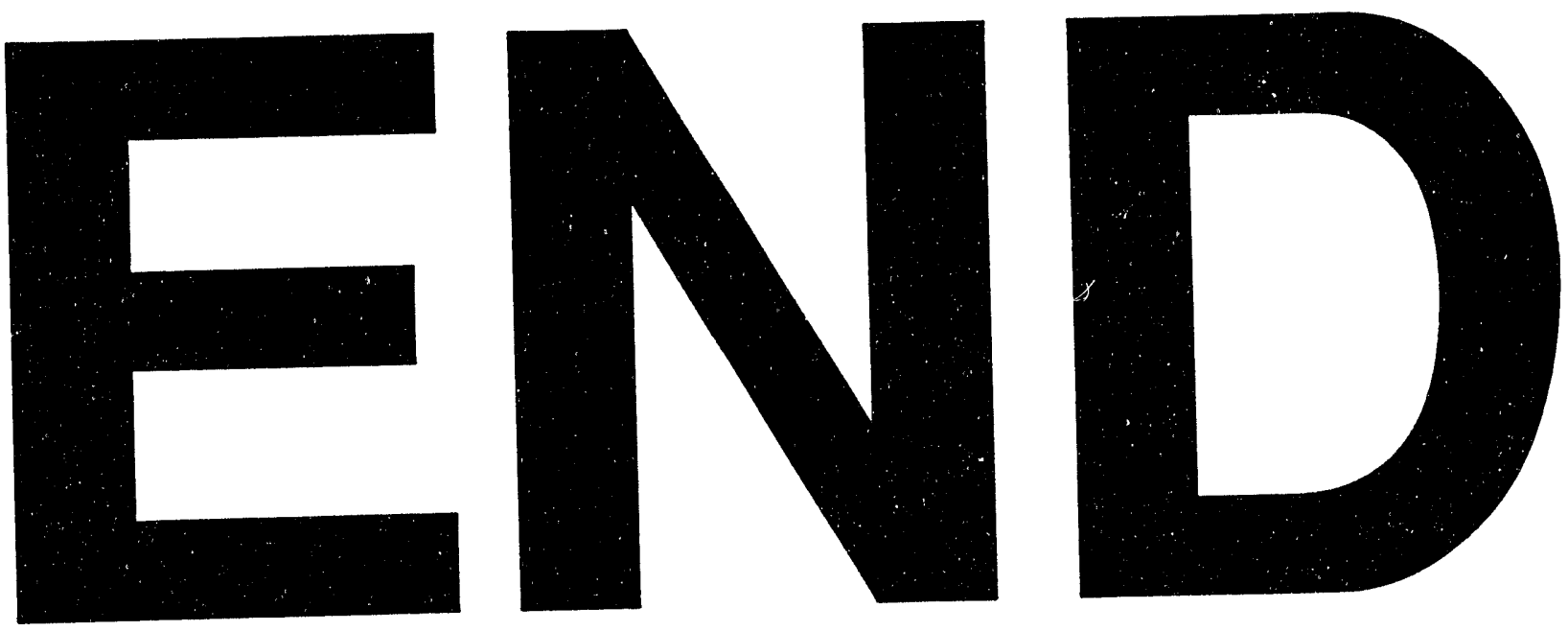


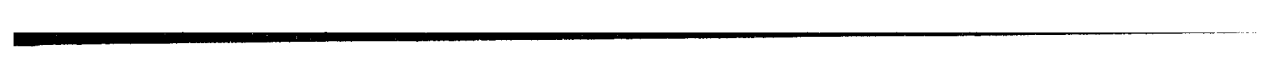

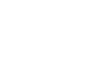

